\title{
Eddy-Current Inspection of Small Cracks in Narrow Spaces by Using Needle-type Magnetic Probe
}

\author{
S. Kanamori, H. Hoang, T. Ueno*, and S. Yamada \\ Institute of Nature and Environmental Engineering, Kanazawa University, Kakuma-machi, Kanazawa 920-1192, Japan \\ ${ }^{*}$ Graduate School of Nature Science and Technology, Kanazawa University, Kakuma-machi, Kanazawa 920-1192, Japan
}

Eddy-current testing (ECT) is one type of non-destructive testing for conductive materials, and it is especially an effective and relatively simple way of inspecting surface defects in conductors. In order to improve the resolution and sensitivity of detection, a needle-type magnetic probe with a spin-valve type giant magneto-resistance (SV-GMR) sensor was developed. This probe can potentially detect defects in narrow spaces, and we therefore propose it to be utilized in detecting cracks inside extremely small grooves and holes in conductors. We discuss the principle of detection and the spatial resolution by referring to experimental results.

Key words: nondestructive testing, eddy current, needle probe, GMR sensor, narrow space, crack

\section{針形状磁気プローブを用いた狭空間内の微小傷に対するうず電流探傷}

\author{
金森周矢・H. ホアン・上野敏幸*・山田外史 \\ 金沢大学環日本海域環境研究センター, 石川県金沢市角間町 (广920-1192) \\ *金沢大学大学院自然科学研究科, 石川県金沢市角間町 ( ⿳920-1192)
}

\section{1. はじめに}

非破壊検査の一つとしうず電流探傷法がある。うず電流探傷 法は，主として非磁性導体の検査対象のキズ検査に用いられてい る. 特に導電体の検査対象の表面上やパイプ内外の表面キズの探 傷に有効であり，小型装置で簡易な方法として利用されている.

一方，リベット穴や加工溝中などのうず電流探傷プローブを挿 入することの困難な検査対象に対しては，センサとキズ間の距離 が大きくなることにより，感度ならびに空間分解能が低下しうず 電流探傷法の利用が困難であった ${ }^{1)-3)}$. mm 以下の大きさのキズや, 導体穴や溝などの狭い空間に生じたキズの検査の必要性が高まる 中，うず電流探傷の利点を保ち，センサ形状等を検討することに より，穴や溝に対しても適用可能な力法について検討した。

著者らは，超小型・高感度の磁気センサである巨大磁気抵抗効 果センサ(GMRセンサ)に注目 ( ${ }^{4) 5) ， か つ G M R セ ン サ チ ッ フ ゚ を セ ラ ~}$ ミックの針形状プローブの先端に搭載した磁気センサとして提案 した6)-8). 針状磁気プローブを利用することにより狭い空間に検出 センサを挿入することができ，穴や溝の内部に対するうず電流探 傷の欠点を解決できる，本論文では，針状磁気センサで構成した うず電流探傷プローブの構成と導体の円筒穴のキズに対する探傷 実験を試み，針状磁気プローブの特性を評価した。

\section{2. 針状磁気プローブを用いたうず電流探傷}

\section{1 針状磁気プローブを用いたうす電流探傷}

\section{(1) 針状磁気プローブの構成}

本研究ではうず電流探傷法を用いるため, 磁気センサを搭載し た針状磁気プローブと外部磁界を発生させるための励磁コイルを 使用している. 針状磁気プローブと励磁コイルの位置関係はFig. 1 に示すような構成になっている. 励磁コイルの形状は矩形状とし, コイルの中心にスピンバルブ形GMRセンサ(SV-GMR)が位置す るように針状磁気プローブを配置している．このため，励磁コイ
ルによってセンサに印加される磁界はFig. 1に示す $z$ 方向が主な成 分となる. 小振幅の交流磁界では, センサの磁界感度方向はFig. 1 のx方向となっている. そのため, センサは励磁コイルによって発 生した磁界の影響は受けず， $x$ 万向の磁界がセンサに印加されるこ とで, 出力を促寸. センササイズは $40 \times 40 \mu \mathrm{m}$ と小型であるため, 局所的な磁界を捉えることが可能である. センサはプローブの先

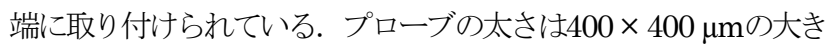
さで, 極細針状になっている. このため, 数mmの溝や穴に対して 針状磁気プローブを穴内部に挿入して走査, 探傷ができる. ただ し，励磁コイルは穴の外部に位置する.

（2）うず電流探傷検査システム

うず電流探傷検査システムのブロック図をFig. 2に示す．外部磁 界を発生させるための励磁コイルには，ファンクションジェネレ 一タとアンプを介して励磁電流を流し，磁界を発生させる，検出

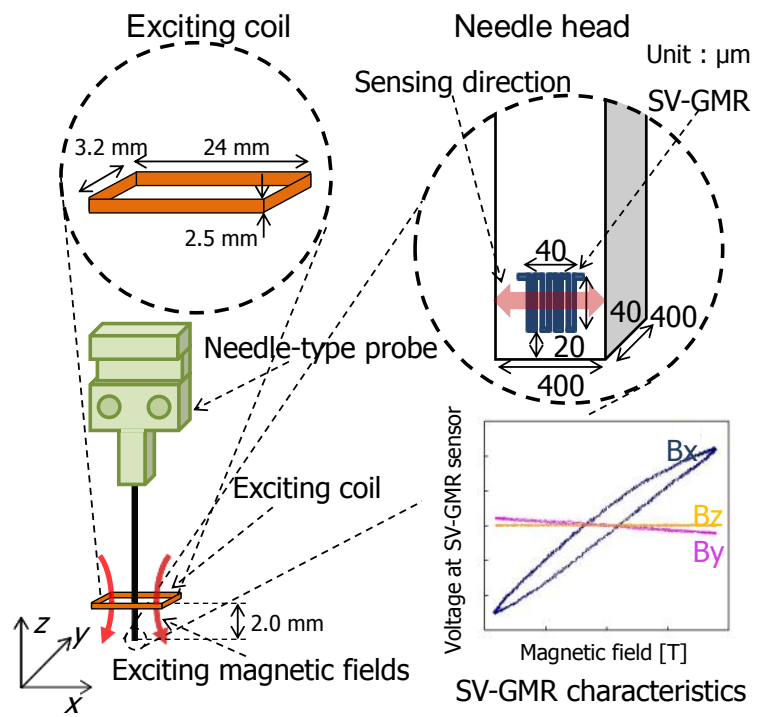

Fig. 1 Needle type GMR probe for eddy-current testing. 
部である SV-GMR センサでは, キズに由来する磁界の変化を検出 する. しかし, プローブの出力には, 外部環境からの電磁気的ノ イズが含まれるので，プローブの出力から励磁周波数以外の成分 を除去する必要があり，ロックインアンプを利用している. ファ ンクションジェネレータからの周波数を参照信号としてロックイ ンアンプに入力して同期させている. そして，プローブの出力か ら励磁周波数と同じ周波数成分の振幅值と位相差を出力として得 ている. PC は設定された座標のデータを得ると, 座標移動の命令 をステージコントローラに送り，検査対象物を自動で走査してい る.

\section{2 円筒穴内部に対するうず電流探傷}

（1）円筒穴内部に対する探傷原理

円筒穴内部の傷の探傷の構造，原理をFig. 3に示す. リベット穴 などの円筒穴の内部にできるキズは, Fig. 3のような穴の側面に沿 った $z$ 方向が長手方向となるキズとする. プローブを円筒穴内部に 挿入し，励磁コイルによって $z$ 方向の磁界を発生させるが，コイル から離れるとr方向成分が表れる. これにより, 検査対象にはファ ラデーの法則にしたがって，外部磁界を打ち消す方向にうず電流 が流れる. キズがない場合には，うず電流は穴の側面に沿って $\theta$ 方向に流れる. 一方，キズがある場合には， $\theta$ 方向に流れるうず 電流は，キズ付近で流れる向きが変化し，キズに沿って $z$ 方向にう ず電流が流れる. このため, キズ付近では $\theta$ 方向の磁界B昰表れ る. SV-GMRセンサの感度方向が $\theta$ 方向であることにより磁界 $B \theta$ の出力電圧が得られる. したがって, プローブの感度方向を $\theta$ 方 向に固定して，穴の側面に沿って走査寸ることで，プローブがキ ズを通過した時には大小の極值をもった信号がプローブから出力 されると考えられる. 信号の振幅は，うず電流の表皮深さとキズ 深さにより変化するので，キズ深さを考慮して励磁周波数を決定 する.

\section{（2）検査対象モデル}

針状磁気プローブの有効性を確認するため, 検査対象として円 筒穴内部の欠陥を想定した．穴内の欠陥は，金属表面からの探傷 は困難である. Fig. 4 に今回対象としたモデルを示す. 試験用モデ ルは厚み $5.0 \mathrm{~mm}$ のアルミニウム板で，円筒穴の直径は $6.0 \mathrm{~mm}$ である. また，板の表面から深さ $1.5 \mathrm{~mm}$ の部分から，板の裏面 まで穴の側面に傷を設けた. 穴内の側面に位置するキズの寸法は, 幅 $1.0 \mathrm{~mm}$, 奥行き $1.0 \mathrm{~mm}$ とした.

\section{3 偏芯の影響低減}

穴内ではプローブは，穴表面に対して一定なリフトオフ高さを 保って， $\theta$ 方向に走査する. しかしながら，一般的には僅かであ るが円筒穴の中心とプローブを走査した際の軌跡が描く円の中心 がずれ，すなわち Fig. 5 に示すように穴と円状の走査において偏 芯 $d$ が生ずる. この偏心により, リフトオフ高さが変化し，また センサのセンシング方向が穴の中心に対する $\theta$ 方向からずれる. キズに基づく磁界信号に対して大きな励磁磁界を印加する状態で は，印加磁界の $r$ 方向の磁界 $B r$ が存在することにより，センサの センシング方向に対するオフセット信号の磁界を生ずる. このよ うな，プローブの走査によるオフセット信号を低減するために信 号処理が必要である.

偏芯時の円筒穴やプローブの軌跡を模式的に表した図を Fig. 5

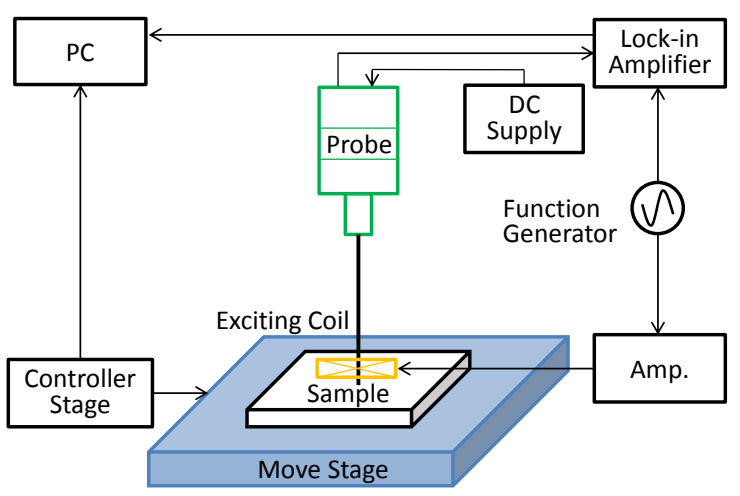

Fig. 2 System for eddy-current inspection.

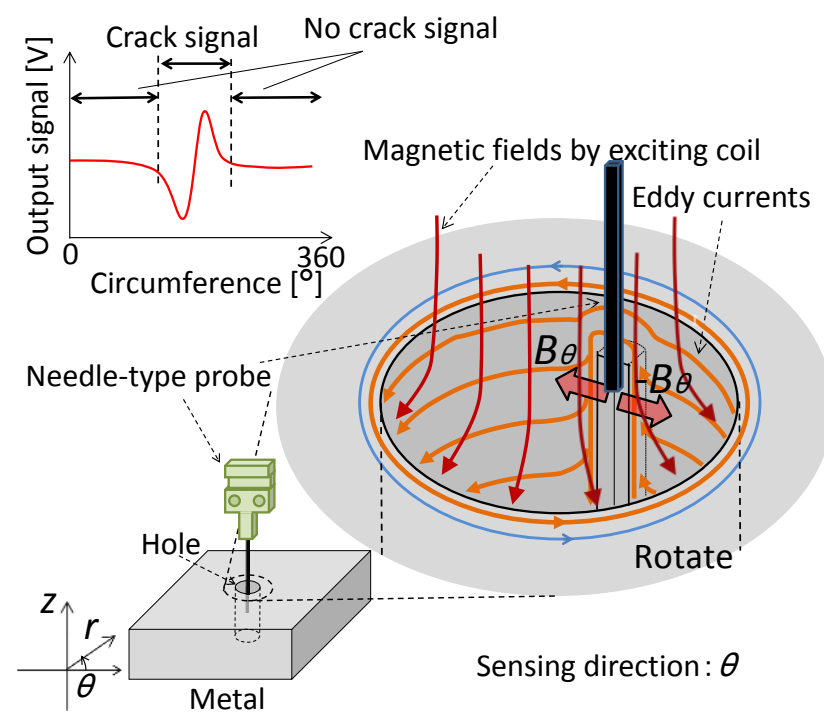

Fig. 3 Principle of inspection for hole structure.
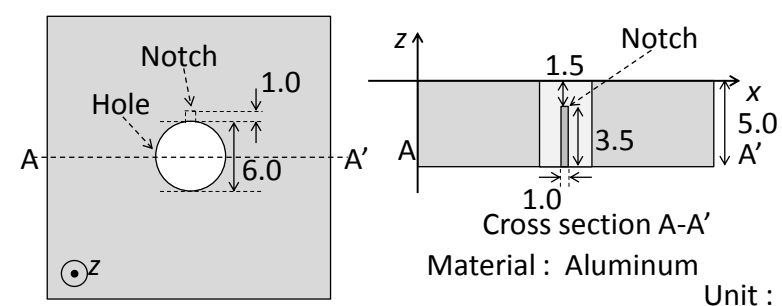

Material : Aluminum Unit : mm

Fig. 4 Test sample with hole structure.

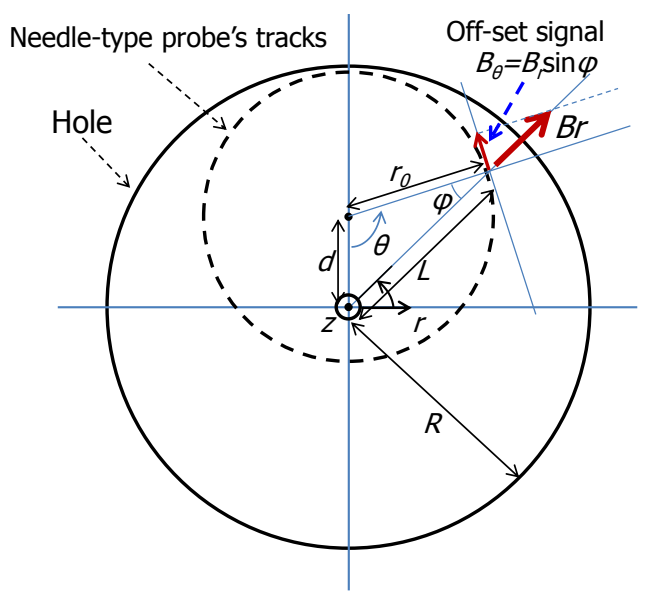

Fig. 5 Off-set signal depending on eccentricity. 
に示寸. センサのセンシング軌跡が，探傷対象の穴から偏芯して いる時, $r$ 方向の励磁磁界ベクトルがセンサのプローブの感度方向 に対寸る成分 $B r \sin \varphi$ となる. Fig. 5 において, 穴の半径 $R$, プロ 一ブの走查角度 $\theta$ は既知であるが, 偏芯距離 $d$, プローブの走査半 径 roは未知である.

針状センサプローブは穴の内面を，穴の半径 $R$ に対して十分リ フトオフ高さが小さくなるように走査するとし, すなわち $d \ll r a$, $r_{0} \doteqdot R$ の条件が成立すると仮定する. この時，穴中心とセンサの 距離 $L$ は,

$$
\begin{aligned}
L & =\sqrt{r_{0}^{2}-2 r_{0} d \cos \theta+d^{2}} \\
& \approx r_{0}\left(1-\frac{d}{r_{0}} \cos \theta\right)
\end{aligned}
$$

と表すことができる.（1)式よりセンサの表面の法線方向から余弦 $\cos \varphi$ は.

$$
\begin{aligned}
\cos \varphi & =\frac{r_{0}^{2}+L^{2}-d^{2}}{2 r_{0} L}=1-\frac{\frac{1}{2}\left(\frac{d}{r_{0}}\right)^{2} \sin ^{2} \theta}{1-\frac{d}{r_{0}} \cos \theta} \\
& \approx 1-\frac{1}{2}\left(\frac{d}{r_{0}}\right)^{2}\left(1+\frac{d}{r_{0}} \cos \theta\right) \sin ^{2} \theta
\end{aligned}
$$

と近似できる.さらに，余弦関数の近似の式，すなわち

$$
\cos \varphi \approx 1-\frac{1}{2} \varphi^{2}
$$

により，(2)，(3)式から，センサの穴の表面の法線に対する傾斜角 $\varphi$ は,

$$
\begin{aligned}
\varphi & =\frac{d}{r_{0}} \sin \theta \sqrt{1+\frac{d}{r_{0}} \cos \theta} \\
& \approx \frac{d}{r_{0}} \sin \theta\left\{1+\frac{1}{2}\left(\frac{d}{r_{0}}\right) \cos \theta\right\} \\
& =\frac{d}{r_{0}} \sin \theta+\frac{1}{4}\left(\frac{d}{r_{0}}\right)^{2} \sin 2 \theta
\end{aligned}
$$

となり，偏芯によりセンサが法線方向から傾斜することによる才 フセット信号 $\Delta V_{\text {offsetは, }}$

$$
\begin{aligned}
\Delta V_{\text {offset }} & =k B_{r} \sin \varphi \\
& \approx k B_{r} \varphi \\
& =k B_{r}\left\{\frac{d}{r_{0}} \sin \theta+\frac{1}{4}\left(\frac{d}{r_{0}}\right)^{2} \sin 2 \theta\right\}
\end{aligned}
$$

と求まる. ここで， $k$ はセンサの感度を表す係数である. Fig. 5 では偏芯の方向を $y$ 軸方向としたが, $y$ 軸からの偏芯方向を $\theta 0$ とす ると(5)式よりセンサの出力電圧は,

$$
\Delta V_{\text {offset }}=V_{1} \sin \left(\theta+\theta_{0}\right)+V_{2} \sin 2\left(\theta+\theta_{0}\right)
$$

となり, $\sin \theta$ および $\sin 2 \theta 0$ 成分からなる.この結果から, プロー
ブを円筒穴に沿って一周走査して得られた実験結果から，基本周 波数成分と第二高調波成分をフーリエ級数展開することにより成 分 $V 1, V 2$ を求め, 原信号から減ずることにより, 偏芯による才八 セット信号を低減できる. 一方, キズ信号は, 周期と異なる信号 であるので除去されることはない.

Fig. 6にキズを設けていない試験サンプルの原信号と信号処理 後の出力の結果を示寸. Fig. 6に示すように, 信号処理前には出力 が周期的に変化していたのが明らかであり, また波形から偶関数 成分(20成分)が含まれていることが明らかである. (5)式に沿ってフ ーリエ級数展開を行うことで，オフセット信号の成分を低減し， 信号処理後にはほぼ一定な信号を得ることができた. 以下の結果 では, オフセット信号の処理を行った結果に対してキズ信号を評 洒した.

\section{3. 円筒穴内部の探傷実験}

Fig. 4の試験サンプルを用いて探傷実験を行った. 実験条件とし て, 励磁周波数は $300 \mathrm{kHz}$ とした. その時の試験材料アルミニウム の表皮深さは0.15 mmであり, キズ深さ $1 \mathrm{~mm}$ より分小さい. 駆 動電流は1.5 mA(実効值)とし, センサ近傍に励磁される磁束密度 $100 \mu \mathrm{T}$ である. 走査範井はプローブをサンプルの表面から円筒穴 の内部に深さ $2 \mathrm{~mm}$ まで挿入した. $z$ 方向の走査ピッチ $0.1 \mathrm{~mm}$, $\theta$ 方向の走查ピッチ $5^{\circ}$, キズが走査角度 $180^{\circ}$ 付近に位置する ように試験サンプルを配置して実験を行った。

プローブをサンプルの表面上，穴の内部に深さ $1,2 \mathrm{~mm}$ 挿入し て走査したときの結果を Fig. 7 に示す. 表面でプローブを走査し たときには, キズが位置している $180^{\circ}$ 付近において出力の変化 が確認できず，キズを検出できなかった，それに対して，プロー ブを穴の内部に挿入して走査した場合には, 走査角度 $180^{\circ}$ 付近 において原理と同様な大小の極值が確認でき，キズを検出できた. プローブを穴に挿入した深さと, キズによって得られた大小の極 值の差としての信号振幅の関係を表したものを Fig. 8 に示す. プ ローブを挿入した深さが $0 \sim 0.8 \mathrm{~mm}$ のときには值に変化はなく, キズを検出できていない. そして, プローブを $0.8 \mathrm{~mm}$ 以上挿入 したときには, キズにより出力が変化しており, プローブの深さ

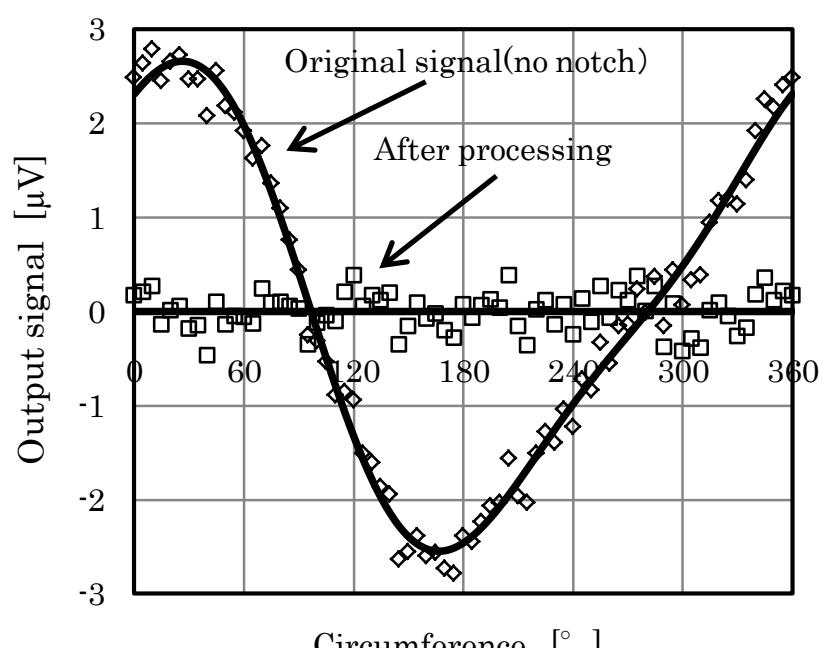

Circumference $\left[{ }^{\circ}\right]$

Fig. 6 Cancellation of off-set signal depending on eccentricity. 


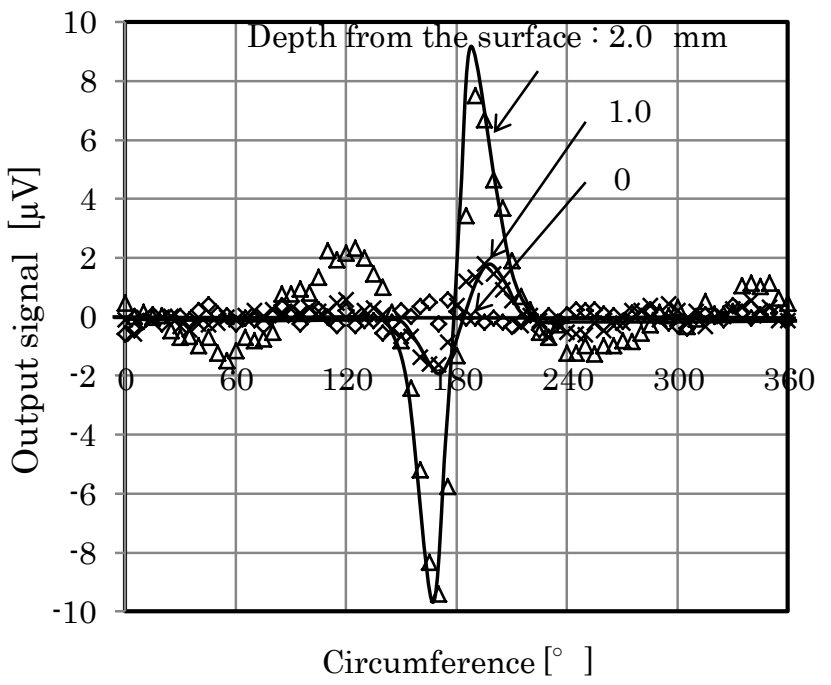

Fig. 7 Dependence of detected notch signal on scanning depth from the $\operatorname{surface}(z=0)$ to $z=2.0 \mathrm{~mm}$ in depth.

が深くなるにつれて，信号は増加傾向になつた. これはプローブ を内部に挿入することで，センサとキズの距離が縮まったためと 考えられる. また，キズが表面から $1.5 \mathrm{~mm}$ 深さに存在すること より, プローブを挿入した深さが $0.8 \mathrm{~mm}$ 以降においてキズ信号 が明確になった. Fig. 3 で示すように, キズの端でのうず電流分布 の広がりにより，キズ信号がキズ手前から増加することと思われ る. Fig. 9 に $\theta$ 方向と深さ方向に 2 次元に走査した結果を示寸. プ ローブを表面で走査したときにはキズを検出できていないが，円 筒穴の内部にプローブを挿入することで原理と同様な大小の極值 が得られている，このことから，提案する針状磁気プローブによ り穴内部にセンサを挿入できることで穴などの狭い空間内のキズ 検出が可能になった.

\section{4. まとめ}

従来の磁気センサでは，プローブの形状や感度，空間分解能な どの制約から，穴や溝内部に生じるキズはプローブを挿入するこ とができず，探傷は困難であった. そこで，本研究では，SV-GMR センサが付いた針形状磁気センサチップで構成したうず電流探傷 プローブを用いて，円筒穴の内部のキズに対してうず電流探傷を 試夕た，実験により，金属表面上では探傷が困難とされていた円 筒穴内部のキズを, プローブを穴内部に挿入して走査することで, 傷信号の検出を可能にした．また，このような狭い空間のプロー ブの探傷では，プローブの走査の不均一によるオフセット信号が 大きく現れることがあり，穴形状に対するオフセット信号の処理 方法を示した.

今回，円筒穴の内部のうず電流探傷を示したが，細溝内のキズ 等に対する探傷についても同様に対応できる，穴や溝内で針形状 のプローブを正確に駆動し，オフセット信号を抑制するためには これまで以上に探傷プローブを駆動するステージの精度が重要と なる.

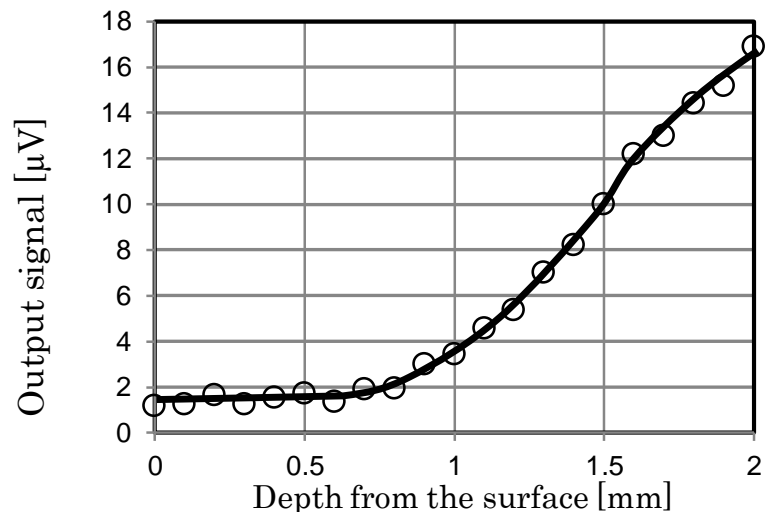

Fig.8 Amplitude of notch signal vs. scanning depth.

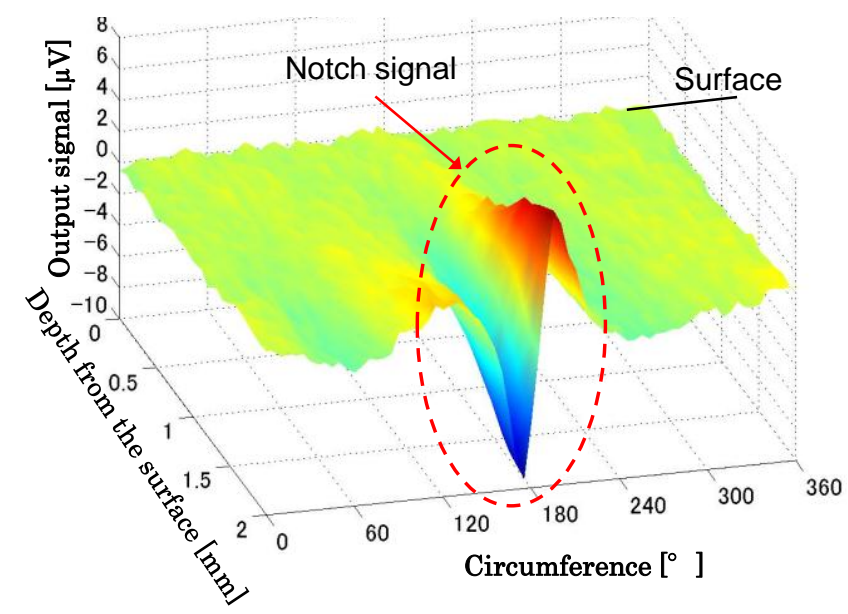

Fig. 9 3-D diagram of notch signal detection.

謝辞 本研究の一部は, 平成22-24 年度科学研究費補助金基盤研究 (B) (課題番号 22360163) により行われた.

\section{References}

1) B.A.Lepine : Review of $Q N D E, 17,355$ (1998).

2) H.-J. Krause, et al : ECNDT, 3, 9 (1998).

3) T. Watanabe, S.Yamada, M.Ito : Denkiseikou, 79, 4, 271 (2008).

4) H.Bayani, M.Nishino, S.Yamada, M.Iwahara: IEEE Trans. Magn., 44, 11, 4015 (2008).

5) A.Lekawa, M.Kakikawa, M.Iwahara, S.Yamada: J. Mag. Soc Jpn., 32, 3, 191 (2008).

6) H.Hoang, R.Haraszczuk, M.Kakikawa, T.Ueno, S.Yamada: J. Mag. Soc. Jpn., 34, 4, 529 (2010)

7) C.P.Gooneratne, M.Kakikawa, T.Ueno, S.Yamada: J. Mag. Soc. Jpn., 34, 2, 119 (2010).

8) R.Haraszczuk, M.Kakikawa, T.Ueno, S.Yamada, M.Nadi: $J$. Mag. Soc. Jpn., 35, 2, 157 (2011).

2012年10月23日受理，2012年11月19日採録 